\title{
UC Berkeley's forestry program celebrates 100 years
}

J. Keith Gilless

Dean, College of Natural Resources, UC Berkeley

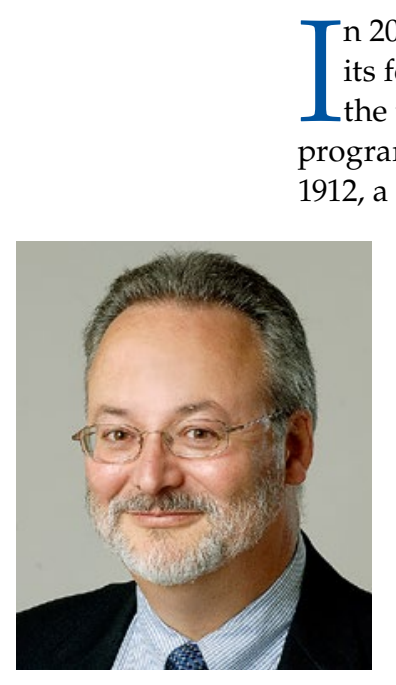

n 2014, UC Berkeley celebrated the centennial of its forestry major. As with many other events in

the university's history, the creation of the forestry program began with a push from student activists. In 1912, a group of agriculture undergraduates started a forestry club that has endured to the present.

They pressed UC administrators and state legislators to establish a major in the subject, and in 1914 the Berkeley campus welcomed the first cohort of students to its new forestry program. Since then, the forestry issues addressed by UC teaching, research and extension programs have changed, but the tradition of serving society and the environment has continued unabated.

This issue of California Agriculture provides an opportunity to reflect on the past 100 years of forestry in California and the important partnership between our campus teaching program and the statewide UC Agriculture and Natural Resources (UC ANR) research and extension programs. All of the forestry faculty in UC Berkeley's College of Natural Resources have appointments in either the Agricultural Experiment Station
With UC forestry experts addressing issues such as carbon sequestration, endangered species, catastrophic wildfire, invasive species and managing forests to enhance water yield, we are confident that our partnerships with the people of this state will remain relevant long into the future. or UC Cooperative

UC forestry community. Two articles highlight work from our educational partners in the California State University system. As we embark on the next century of forestry education in California, it has never been more important that UC Berkeley, Humboldt State and Cal Poly San Luis Obispo - which host the state's three accredited forestry educational programs work together to educate a new generation of foresters. They will need a solid foundation to meet the high standards of California's licensing requirements and work successfully under the close public scrutiny of forest management demanded by the California Forest Practice Act.

Two UCCE advisors, Michael De Lasaux in Plumas and Sierra counties and Glenn Nader in Sutter, Yuba and Butte counties, authored an article about exciting grassroots extension partnerships with California's fire safe councils. The article on the Sierra Nevada Adaptive Management Program (SNAMP) by UC Berkeley Professor Lynn Huntsinger, UCCE Central Sierra Forestry Advisor Susan Kocher and UC Berkeley researcher Adriana Sulak illustrates UC ANR's effectiveness in bringing cutting-edge science to key forestry issues - fire management, wildlife habitat and water quality — faced by people across the state.

The Center for Forestry (ucanr.edu/sites/cff) coorExtension (UCCE). They often work closely with the statewide network of UCCE forestry and natural resource advisors based in county offices and the UC ANR research and extension centers.

The articles in this issue show the range of research being conducted by the extended dinates much of the forestry research and extension work at UC Berkeley and also manages four forest properties. The article by the center's property manager, UC Berkeley Professor Robert York, describes a project in the crown jewel of California's research forests, Blodgett Forest Research Station in El Dorado County. Blodgett and our other properties are essential for outreach activities, helping to ensure that research is adapted and understood by the wide variety of stakeholders in California's forestland. We are excited for the future of our research forests, and have recently finalized plans to assume title to lands previously managed by Pacific Gas and Electric Co. that will bring our research forest footprint to 10,000 acres.

On September 19, 2014, more than 350 of our alumni, faculty, staff and friends gathered at the UC Berkeley Faculty Club to celebrate 100 years of forestry in California and recognize a century of accomplishments. Now we look forward, embracing the challenges of ensuring sustained uses of California's 40 million acres of forests and woodlands. With UC forestry experts addressing issues such as carbon sequestration, endangered species, catastrophic wildfire, invasive species and managing forests to enhance water yield, we are confident that our partnerships with the people of this state will remain relevant long into the future. $\mathrm{CA}$ 